Mock Moons

I NEVER noticed that mock moons and mock suns are not always at the same altitude as the moon or sun, but I would point out that when objects are high up, it is very difficult to decide on their relative altitudes. If mock moons are at the same altitude as the moon, then of course they are not on a great circle, but on a small one, and in consequence, except when they are low down, a straight line passing through the mock moons will pass above the moon, and when they are high up, at a considerable distance above it. In such a case, if the observer does not look straight at the moon, he may easily suppose that one of the mock moons is higher up than the other. Is your correspondent (vol. xxvii. p. 6c6) sure that they were not at the same altitude on the occasion he refers to? If, instead of facing the moon and looking straight at it, he looked more at the righthand mock moon, the illusion would be produced of the left. hand one appearing higher up. The same illusion is caused when the horizontal lines of buildings or of a window cut the line passing vertically through the moon obliquely ; so that great care is required in making these observations.

I might add that I observed the mock moons and halos on the evening alluded to (April I6) from Sunderland till after I I p.m., and that I noticed nothing unusual in their positions or size. The mock moons (or sun:) are always outside the ordinary halo when their altitude is considerable. On that occasion there was also visible a considerable part of the horizontal halo passing through the mock moons, forming long tails to them away from the moon; also vertical and horizontal rays proceeding from the moon ; forming a faint cross with the moon at its centre. The horizontal rays were narrow, and reached at one time to the ordinary halo, but were much fainter than the "tails" of the mock moons. The vertical rays did not reach quite so far, and were broad and indefinite; otherwise I suppose their character (except as to brightness) wuuld be much the same as that of the "sun pillar" described by several of your recent correspondents.

Sunderland, May I2

\section{Helix pomatia}

ALTHovgh this species is decidedly local in this country, yet it is interesting to note that the counties in which it has been recorded are contiguous to one another. Its course of ditribution appears to pass through Kent, Sussex, Surrey, Hants, Wilts, Glouce tershire, Berks, Oxon, Bucks, Herts, and Northamptonshire, and this seems to support Mr. Stokoe in his suggestion (NATURE, vol. xxviii. p. 6) that it may be a geologically recent importation from France (to the northern portion of which it is confined in that country).

In Murray's "Handbook to Surrey," p. 7o, Helix pomatia is stated to abound at Tyting Farm near Guildford, "said to have been introduced from Italy "by an Earl of Arundel, and Bevan's "Guide to Surrey," p. II I, mentions the same locality as the "habitat of the edible snail imported from Italy," \&c. I vi-ited this spot in September, I880, in quest of $H$. pomatia, and mentioned my object to a farm labourer, who speedily produced three specimens from under a $\log$ of wood, but told me that they were not at all plentiful there, as the soil was sandy and not chalky, and he said I mu-t look for them on the neighbouring chalk downs, whence his master the farmer procured his for the purpose of adopting the diet, which, when ill, he had been advised to try. Be H. pomatia indigenous or not, there is no doubt its presence in England has been assi:ted by importations, for $\mathrm{Mr}$. Lovell Reeve mentions its being introduced from Italy by an English nobleman in the vicinity of Box Hill and Reigate (cf. also Gray's "Turton," ed, I840, p. 35).

The Helix scalaris referred to in Venables' work on the Isle of Wight is cited in that book as a mon-trosity of H. aspersa, and Moquin Tandon's figure of the variety scalaris is of the u-ual coloration of that species. The name, however, $u$ as originally bestowed by Muiller on a variety of $H$. pomatia (Lamk. "An sans vert," second edition, vol. viii. p. 32), and is figured as such by Draparnaud, but Venables' reference seems to apply to a scalariform variety of $H$. aspersa observed by Dr. Gray near Ventnor.

W. C. ATKINSON

Streatham, S.W., May II

\section{Cape Bees}

I CAN endorse all that Sir J. H. de Villiers says concerning the sense of smell in the wild bees of the Cape. The aver:ion they have to sweating horses is well known, as also to the scent of chopped carrots. The following. instances of this have conce under my own notice:-

A party of young men who had been springbok hunting all the morning, off-saddled their hor es during the hottest pait of the day, under the shadow of a great krantz (cliff); they had but ju-t tied them to some Irees, when the poor animals were attaclied in the most vicious manner by an immense swarm of rock bees from the krantz, and so dreadfully were they stung, that, although the thongs that bound them were cut through as quickly as possible to enable the poor things to escape, one beautifu. horse was stung to death, and two more of the number were so maddened that they galloped off, and for many days were quite unfit for use.

One of the Hottentot children upon our place, playing in the garden near some hived wild bees, mischievously chewed up a carrot, and spat it into the entrance of the hive; the boy was perfectly naked, and the next few minutes might have been his last, had not the European gardener happened to be near, and hearing his shrieks, hastened to the spot, thrust the child into a newly-dug trench, and quickly covered bim with earth; but he had a narrow e:cape of his life, for he was literally covered with stings.

The precursor of a storm in the Karoo is generally a whirl. wind of dust, and our boys used to take advantage of the dislike to storms evinced by bees, to throw up large handfuls of dust into the air, when a swarm was passing overhead, when sometimes the bees would be deceived and settle immediately.

Late of Graaff Reinet, Cape of Good Hope

M. CAREY-Hobson

\section{The Effect of the Change of Colour in the Flowers of "Pulmonaria officinalis" upon its Fertilisers}

YESTERDAY I had an opportunity of convincing myself by direct observation that the change of colour in the flowers of Puimon. aria officinalis is of the same significance as in Ribes aureum and Lantana, according to Delpino and Fritz Müller (ompare NATURE, vol. xvii. p. 79).

In a small locality about twenty yards long and two broad, where many bundred flowers of Pulmonaria were in all stages of development, its principal fertilisers were the females of Anthophora pilipes, F.; they visited almost exclucively the red flowers and those just beginning to change towards blue, but only exceptionally blue ones.

The first individual which I watched when it was flying from flower to flower did so without any exception. Another individual newly alighting on the place at first now and then visited one or some few blue flowers, but the longer it continued its predatory flight the more it neglected the blue flowers and selected only the red ones.

A third female of Anthophora which I followed indiscrimin. ately visited (a) red flowers of Pulmonaria, (b) large blue floners of Glechoma, both in the following order:- $(a) \mathbf{I} 6,(b) \mathrm{I},(a) 23$, (b) I, (a) 21, (b) 62, (a) 5 flowers ; then it left the place without having touched a single blue flower of Pulmonaria.

The fourth and last female of Anthophora I followed neglected completely the flowers of Glechoma; but when it visited the red flowers of Pulmonaria and met for some time only with already emptied ones, it became more and more disturbed and hurried, and then indiscriminately visited blue and red flower: until anew it found honey in a red one. It visited $(a)$ red and $(b)$ blue flowers of Pulononaria in the following order :-(a) 52 , (b) I, (a) $18,(b) 3,(a) 16,(b) 1,(a) 34,(b) 3,(a) 7,(b) 1,(a) 42,(b) \mathbf{1}$, $(a) 13$; in summa $(a) 182$ red, $(b)$ Io blue floners.

It is easy to be seen whether a flower of Pulmonaria when visited by Anthophora contains some honey or not; in the first case the proboscis of the bee rests at least $\mathbf{I}$ to $\mathrm{I} \frac{1}{2}$ secords in the corolla tube, whereas in the other case it is instantly withdrawn. All blue flowers of Pulmonaria which were visited preved thus to be empty of boney, and in all which I examined with a lens in this locality the stiyma was supplied with pollen.

We may, I think, safely conclude from these observations that the blue colour of older flowers of Pulmonaria, whilst increasing the conspicuousne-s of the clusters of flowers, at the same time indicates to such intelligent bees as Anthophora to which flowers they have to restrict their visits as well to their own as to the plant's profit.

Lippstadt, May 8 